\title{
Подбор маркеров хлоропластной ДНК для анализа изменчивости Caragana jubata
}

\author{
Бессонова В.А. \\ Институт экологии растений и животных УрО РАН, Екатеринбург, Россия \\ Уральский федеральный университет им. первого Президента России Б.Н. Ельцина, \\ Екатеринбург, Россия \\ bessonova-varechka@mail.ru
}

Ключевые слова: Caragana jubata, молекулярно-генетические маркеры, Тибетское плато, филогенетика, гаплотип

Мотивация и иุель: Общность Тибетско-Гималайской и Дальневосточных флор неоднократно отмечалась ботаниками на видовом и родовом уровнях [1]. Caragana jubata (Pall.) Poir. - яркий пример флористических связей между данными регионами. Широкое использование караганы гривастой в народной медицине Восточной Сибири ведет к истощению природных популяций. Поэтому очень важно знать генетическую изменчивость данного вида [2]. Знания о генетическом разнообразии популяций необходимы для реконструкции истории расселения вида, выявления генезиса Сибирской и Дальневосточной флор, а также разработки программ по сохранению биоразнообразия.

Meтоды $и$ алгоритмы: Всего проанализировано 47 образцов: 29 особей из Тункинского района Бурятии, 16 - из Ольского района Магаданской области и два - с юго-востока Тибетского нагорья. Также из Genbank были взяты соответствующие последовательности $C$. jubata китайского происхождения. На первом этапе проводили тестирование 16 универсальных пар праймеров к межгенным спейсерам хлоропластного генома. С парами праймеров, обнаруживших стабильную амплификацию, проводили секвенирование.

Результаты: В результате выявлено два полиморфных маркера, atpH-atpI и участок TabEF региона trnT-trnL. Сочетание изменчивости по ним выявило 7 гаплотипов. Выборка из Бурятии отличается повышенным разнообразием, здесь обнаружено 4 гаплотипа. В образцах из Магаданской выборки - 2 гаплотипа. У тибетских образцов - 1 гаплотип. Оказалось, что популяции из Бурятии и Магадана близки к Тибетской популяции, но при этом отличаются друг от друга. В Сибирской и Дальневосточной частях ареала наблюдается полиморфизм.

Заключение и доступность: В ходе работы отобраны молекулярно-генетические маркеры, перспективные для более детальных исследований на большем объеме материала. Выявлена дифференциация выборок из трех географических регионов. Обнаружена мутация, косвенно указывающая на связь популяций побережья Охотского моря с популяциями из восточной части Тибетского нагорья.

\section{Список литературь}

1. Duan L., Yang X. A molecular phylogeny of Caraganeae (Leguminosae, Papilionoideae) reveals insights into new generic and infrageneric delimitations. PhytoKeys. 2016;70:111-137.

2. Чурюлина А.Г., Бочарников М.В., Огуреева Г.Н. География караганы гривастой (Caragana jubata (Pall.) Poir.) и ее фитоценотическая роль в растительном покрове гор. Вестн. Моск. ун-та. Сер. 5. География. 2020;3:108-117. 